\title{
Oil and Governance in Uganda
}

\author{
Terrell G. Manyak \\ Department of Public Administration \\ Nova Southeastern University \\ 3301 College Avenue, Fort Lauderdale, FL 33314 \\ Tel: 954-262-8091Ｅ-mail: manyak@nova.edu
}

Published: March 17, 2015

doi:10.5296/jpag.v5i1.7170

URL: http://dx.doi.org/10.5296/ jpag.v5i1.7170

\begin{abstract}
Many critical governance issues were created with the discovery of major oil deposits in Uganda. Because developing countries like Uganda lack strong institutional foundations, it is widely assumed that riches flowing from oil will result in huge sums of money being diverted to politicians while the country ends up worse off in the long run. Uganda certainly faces this "natural resource curse," but the potential for corruption is only one of many governance issues arising from the potential of oil riches. The government needs to work effectively with foreign oil companies and neighboring countries to recover and transport the oil. It must also establish institutions and procedures to manage its new oil economy. Moreover, questions must be answered regarding ownership the oil producing lands and how the fragile environment of the country can be protected.
\end{abstract}

Keywords: East Africa, Uganda, governance, petroleum, property rights, environment 


\section{History of Oil Exploration in Uganda}

Villagers in the Albertine Graben region of Uganda have long told stories of oil seepages that attracted the attention of Europeans. However, the first systematic study of oil potential was not pioneered until the early $1920 \mathrm{~s}$ when E. J. Wayland concluded that potentially recoverable petroleum deposits had formed in the area. This finding led the African-European Investment Company of South Africa to drill shallow wells in 1936 and 1937 that revealed layers of oil shale. Further oil exploration was then postponed because of World War II and then suspended by the British in 1962 with Uganda's independence. Interest in finding recoverable oil deposits was rekindled in the 1980s during Milton Obote's second regime following the successful recovery of oil in neighboring South Sudan. An aeromagnetic survey yielded very positive results in three major sub-basins in the Albertine Graben. The government responded to this finding by adopting the Petroleum (Exploration and Production) Act in 1985 to begin serious oil exploration and extraction (Kashambuzi \& Mugisha, 2003; Kiiza, Bategeka, \& Ssewanyana, 2011).

Oil exploration was once again postponed with the overthrow of the Obote regime in 1986. The lack of interest in following up on the findings by the country's new leader, General Yoweri Museveni, was reportedly the result of inadequate funding and the lack of reliable data (Mawejji \& Bategeka, 2013). Museveni later claimed that he had been hesitant about conducting further oil exploration out of "economic patriotism" (Kiiza et al., 2011). He claimed that he could have signed contracts with Shell BP and Exxon, but feared that he would be selling the country's interests short because Uganda lacked people who were scientifically knowledgeable about petroleum. His strategy, instead, was to send Ugandans to foreign universities for advanced studies in oil-related disciplines. These students could then return to provide the technical leadership needed by the government in pursuing oil recovery.

Uganda resumed the search for recoverable oil in 2008 through the Management and Mineral Resources Project after obtaining financial and technical support from the World Bank, the African Development Bank, and the Nordic Development Fund. Under this project, the government undertook the necessary studies to confirm the presence of commercial grade oil deposits. Several foreign oil companies were then licensed to conduct oil drilling operations in the Albertine Graben (African Development Bank, 2009). This region is located in the western part of Uganda, mainly in the Masindi, Kibale, and Hoima districts around Lake Albert. It extends from the northernmost part of the western rim of the East African Rift Valley to the border with South Sudan (see Figure 1).

The most important of the exploration companies, London-based Tullow Oil, gradually consolidated control over the oil-rich blocks in the Albertine Graben. Tullow then sought additional field development experience and investment capital by signing contracts with the French company Total S.A. and the Chinese National Offshore Oil Company (CNOOC) Ltd., granting each of them one-third interest in the exploration area (Mawejje \& Bategeka, 2013). While production of commercial grade oil is not expected until 2017, production is predicted to reach 3.5 billion barrels (bbs) along with 500 billion cubic feet of natural gas reserves over at least a 30 year period (Wiebelt, Pauw, Matovu, Twimukye, \& Benson, 2011). This estimate 


\section{Macrothink}

Journal of Public Administration and Governance

ISSN 2161-7104 2015, Vol. 5, No. 1

was revised upward to 6.5 bbs by the oil companies, but the recoverable oil increased only marginally from 1.2 bbs to 1.4 bbs (Musoke, 2014). The International Monetary Fund expects oil revenues to boost Uganda's Gross Domestic Product by 25\% (Musisi, 2014).

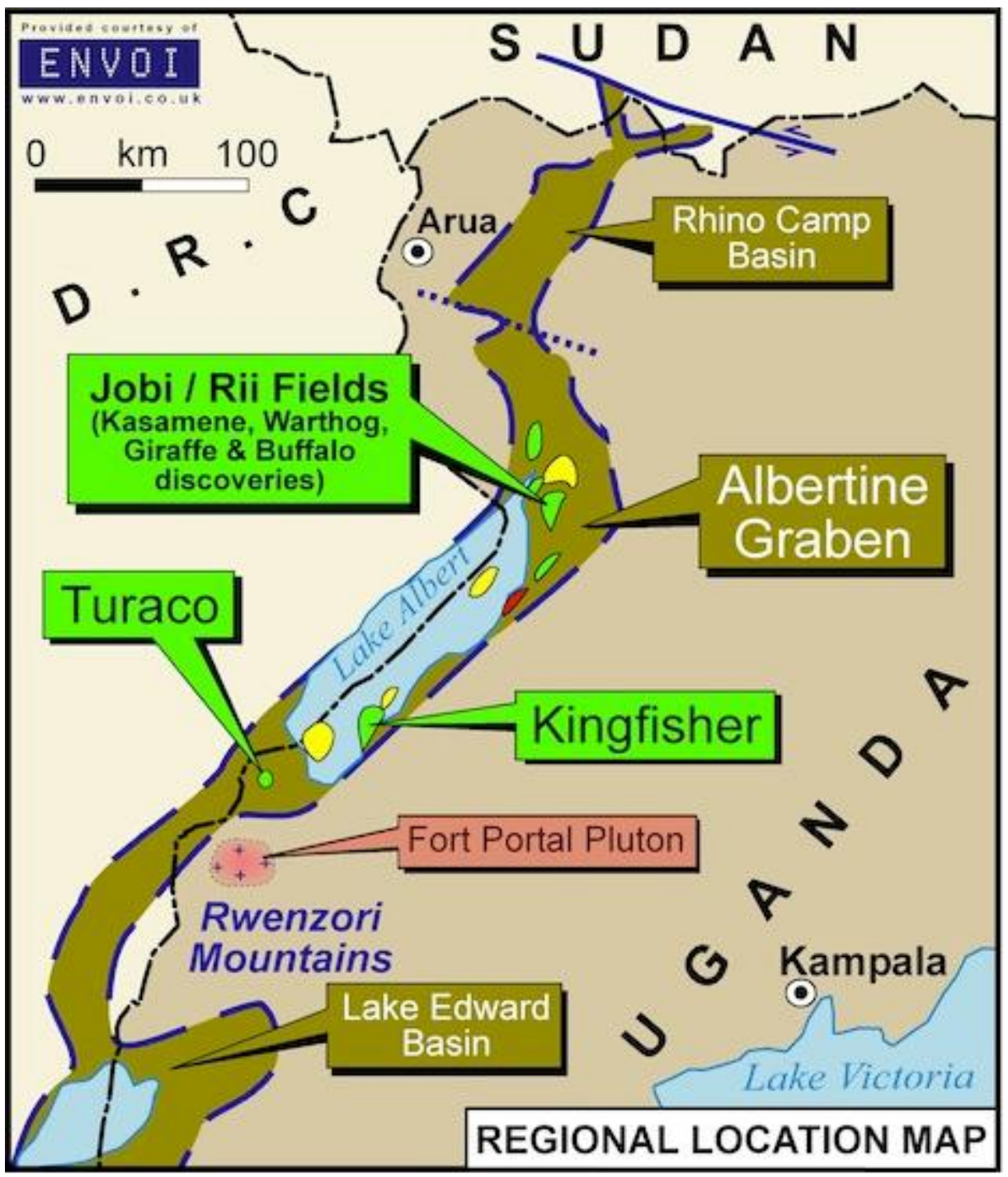

Figure 1. Potential oil producing region of western Uganda.

Retrieved from http://www.geoexpro.com

The Albertine Graben oil field is projected to produce potentially 200,000 barrels of oil per day. The nearby fields in Maputa and Waraga will produce 100 to 400 million barrels of oil. The Giraffe 1 field contains an estimated 400 million barrels, and the Kingfisher field holds approximately 500 million barrels (Uganda Oil \& Gas Documentation Bureau, 2014). Based on seismic data and oil company experience, these estimates assume a recovery factor of 30 percent (Henstridge \& Page, 2012). Overall production of 100,000 to 200,000 barrels per day is possible over 20 to 40 years depending on the speed of extraction (Uganda economy, 2014). The World Bank estimates Uganda's total oil assets to be worth $\$ 75$ billion, which is five times the country's 2010 national GDP (Choudhury et al., 2012). 


\section{Commercial Oil Recovery and Production}

Uganda's next challenge after the discovery of recoverable oil was to find a way to convert the crude oil into a commercially viable product while satisfying the conflicting demands of key stakeholders. The oil companies insisted that transporting the highly "waxy" crude oil hundreds of miles through very difficult terrain to ports in Kenya or Tanzania was critical to the economic viability of the project. At the same time, the Uganda government claimed its primary concern was to satisfy local consumer demand for affordable refined petroleum products. Further complicating the governance situation were the geopolitical interests of the region. Uganda and Rwanda have intense political and economic interests in the Democratic Republic of the Congo, which shares access to the oil field in Lake Albert. Kenya and Tanzania continually joust for political and economic leadership through their control of port facilities on the Indian Ocean. South Sudan desperately wants an option to the Red Sea pipeline that is controlled by the Republic of Sudan. Another complicating political factor is the political future of President Museveni (Opinion poll, 2014). While firmly entrenched as president for three decades, Museveni could see his future as leading the newly formed East African Community (Cooperation, 2013).

Negotiations on how to proceed in extracting and processing the oil deposits took seven years before an agreement was reached in 2013. The oil companies agreed to build a \$4.27-billion oil refinery and crude oil pipeline to the Indian Ocean with a link to South Sudan. A related project calls for the extension of a finished product oil pipeline from Kenya to Uganda. This project is part of the broader agreement between Burundi, Kenya, Rwanda, South Sudan, Tanzania, and Uganda to lay the groundwork for the economic and political integration of the East African Community.

The oil companies objected to the initial government proposal for an 180,000 barrel-per-day refinery as being far too costly (Karugaba, 2013). The final agreement calls for a much smaller 30,000 bpd facility (Hart Energy, 2013). The $\$ 2.5$ billion oil refinery will be constructed in the Hoima district, just east of Lake Albert, by two Russian firms and a South Korean consortium. The refinery should have sufficient capacity to satisfy the consumer needs of Uganda and East African Community (Gelb \& Majerowicz, 2011). The Uganda government also views the refinery as a way to delay the depletion of its oil deposits and enable better management of its oil generated revenues (Hart Energy, 2013).

The crude-oil pipeline project demanded by the oil coalition will be 1,380 kilometers ( 860 miles) running from Uganda's oilfields to Port Lamu on Kenya's northern coast. The additional piers needed at Port Lamu for shipping the oil are being constructed by CNOOC. The agreement also includes the construction of pipeline links from the oilfields in South Sudan as well as from the newly discovered fields in Ethiopia and Kenya. A unique feature of the new pipeline will be a specialized heating system to maintain the liquidity of the crude oil and keep the waxy crude substance flowing at an ambient temperature (Kagai, 2014).

The refined-product oil pipeline will distribute processed oil from the Hoima facility at an estimated cost of $\$ 97$ million. The project will extend the existing Mombasa to Eldoret, Kenya, pipeline some 352 kilometers (217 miles) to Kampala, Uganda, and eventually to 
Rwanda and then Burundi. This pipeline would handle about 30,000 barrels per day and will be configured with a reversing mechanism so that finished oil products from the Hoima refinery can be delivered to Kenya (Region, 2013). This project will be supplemented with the construction of roads, railways and other infrastructure projects to integrate the East African Community. Agreements were also been made to facilitate trade through streamlined one-stop border crossings, adopting an East African identity card and a single tourism visa, and a mutual defense agreement (Kasasira, 2013).

Much of the financing for these projects will be in the form of concessional loans from China. The China Import and Export Bank (Exim) is expected to provide $\$ 2$ billion to fund the development projects. In return, CNOOC was granted the first production license to begin pumping oil from the Kingfisher field and the Chinese state-owned Sinohydro Corporation will build a 600-megawatt hydroelectric station on the White Nile near the oil fields (Ojambo, 2013). Another Chinese company was contracted to build a standard-gauge railway from Mombasa to Nairobi and then to Kampala with later extensions to Rwanda and South Sudan (Deal, 2014). This growing reliance on Chinese funding reportedly gives President Museveni more direct control over the Uganda economy because China demands much less accountability than do western donors (Massive, 2014). Western countries have remained quiet regarding this move toward "economic nationalism" largely because President Museveni is viewed as a stabilizing factor in this highly volatile region (President, 2013).

\section{Governance of Oil Development}

Progress in bringing the oil recovery project to fruition in Uganda has placed increased attention on the need for a strong governance system to ensure that oil wealth will be used for the long-term betterment of the country (Kamugisha, Muhereza, \& Elima, 2008). Underling the call for improved governance is the fear that Uganda will experience the same "natural resource curse" that has plagued most resource-rich African nations. Rather than spur development, it is believed that countries with an abundance of a natural resource end up performing more poorly than do resource-poor countries because they squander their riches through corruption, violent conflicts, and environmental destruction (Ghazvinian, 2007). The proposed antidote for avoiding this outcome to create strong institutions that will assure transparency and effective economic management (Bainomugisha, Kivengyere, Tusasirwe, 2006; Kiiza et al., 2011; Mugyenyi, Ustin, \& Twesigye, 2010).

The natural resource curse is very much on the minds of Ugandans as well as the international community. The fear is that the Museveni regime will use the expected oil income to further entrench its domination of the country (Gelb \& Majerowicz, 2011). This fear is particularly real given Uganda's recent history. The very essence of the Bush War, led by then General Museveni, was to overthrow the infamous Idi Amine and Milton Obote regimes and return proper governance to the country. Following the adoption of a new constitution in 1995, Uganda was heralded as an example of a country building its institutional capacity and working toward a positive future (Andrews \& Bategeka, 2013). However, this image has increasingly come into question as President Museveni is accused of undoing reforms in order to win elections and maintain his three decades long control of the 
government. Examples of these actions are the elimination of presidential term and age limits, the weakening of local governments to engender political support (Manyak \& Katono, 2010, 2011), and questionable measures taken to undermine political opposition (Conroy-Krutz \& Logan, 2012).

Several governance issues related to avoiding the resource curse are before the Uganda parliament and will undoubtedly become election issues in 2016 as potential candidates vie for political advantage. The important of these governance issues are the need to: (1) Assure the proper fiscal management of oil royalties through transparency and accountability; (2) reimburse kingdoms, local governments, and citizens impacted by oil development; and (3) effectively manage the natural and ecological resources that will be impacted by the recovery and processing of oil.

\subsection{Public Finance Management Bill}

The Ugandan parliament is presently creating legislation that will have a major impact on how the country manages its oil revenues. The most important of these governance laws is the Public Finance Management Bill. This law was in large part motivated by Denmark, Ireland, Norway, and the United Kingdom's decision to suspend financial aid to Uganda in reaction to the report of embezzlement of \$12.6 million in donor funds from the Office of the Prime Minister (Mulondo, 2012). To reestablish relations, the Public Finance Management Bill creates a framework for managing oil revenues and consolidating previous public finance management legislation. It also strives to improve budget administration, clarify the role of parliament, and provide for emergency responses to oil revenue fluctuations.

The Public Finance Management Bill represents a positive start in managing the future oil economy, but concerns have been raised about key sections. First, the bill grants full power to the Minister of Energy and Mineral Development to license and create oil regulations. Given the broad impact of oil production, it is felt that, where appropriate, views of other ministries should be taken into account. Second, opponents perceive parliamentary powers as being diminished in favor of the executive branch with respect to financial controls and management of petroleum revenues (CSCO, 2012). Third, several clauses appear to hamstring parliament's ability to control matters of finance and provide oversight of oil revenues (Kaija, 2013; Walubiri \& Mulondo, 2014). Finally, responsibilities are left unclear among the many agencies that will be involved in handling oil revenues. Should problems arise; the vague regulations will make it very difficult to identify the source of the problem and ways to correct it (Suruma, 2014).

A key element of the Public Finance Management Bill is the establishment of an investment fund as a separate government account for the deposit of oil revenues. A well-managed fund can serve as an effective public investment strategy for averting shocks to the economy resulting from the sudden influx or drop in oil revenues. These funds could then be used to make large scale investments in projects that will enhance economic development and reduce poverty. Several studies have focused on developing a specific investment strategy for using oil dollars to transform Uganda (Collier, 2011; Dorosh \& Thurlow, 2009; Mawejji \& Bategeka, 2013; Wiebelt et al., 2011; Wiebelt, Schweickert, Breisinger, \& Böhme, 2011). The 
immediate governance problem is the potential for misuse of such funds through nepotism and corruption. This problem is best countered by creating a transparent process for determining how such money is to be spent or saved each year. The resource rich nations of Botswana, Ghana, Norway, Timor-Leste, and the United Kingdom are held up as models for establishing fiscal rules on investment funds (Uganda economy, 2014).

\subsection{Petroleum Development Acts}

Two other laws adopted in 2013 after months of heated debate were the Petroleum (Exploration, Development and Production) Act and the Petroleum (Refining, Conversion, Transmission and Midstream Storage) Act. The purpose of the Petroleum Acts is to implement Article 244 of the Uganda constitution that vests all minerals and petroleum in the government to use on behalf of the Republic of Uganda. The Acts regulate all phases of exploration, development, transportation and marketing of Uganda's oil and gas resources. They give the Minister of Energy and Mineral Development broad discretionary powers to grant and revoke licenses, negotiate contracts, approve field development plans, and assure transparency in the oil and gas sector. The laws also establish the National Petroleum Authority and the National Oil Company. These agencies will be responsible for managing the development and marketing of the oil and gas resources on behalf of the government.

The Petroleum Acts contain numerous clauses dealing with the regulation of licensing. While rather technical, a recurring concern is the need to ensure transparency and open competition. For instance, the law contains no provisions for competitive bids in awarding exploration and production licenses (CSCO, 2010). It is suspected that some clauses, if not carefully managed, can result in a petroleum production monopoly in Uganda. A key to successful management would be to make licensing information available for public assessment. Unfortunately, the Petroleum Acts give the executive branch full authority to set fees for access to information, limit access to the terms of oil agreements signed by the government and licensees, and provide licensees the right to deny access if a person is not a government official. While justifications can be found for these provisions, it is of concern that transparency can be easily undermined with the public given no recourse for legal action.

An option to the present approach would be to vest licensing authority in the national Petroleum Authority because the agency is intended to be independent of the Minister of Energy and Mineral Development (Human Rights Network-Uganda, 2012). The government responds to this option by noting that Article 244 vests all control of mineral and petroleum resources in the government. While parliament makes laws regulating the exploitation of these sources, the president appoints ministers and they are answerable to him. As expressed by Prime Minister Amama Mbabzzi, “... removing the minister is tantamount to removing the President from control of the oil resources" (Etukuri, 2012, para. 5). Consequently, the Petroleum Acts effectively exclude parliament and the independent National Petroleum Authority from participating directly in the licensing process and approving plans for oil field development.

The government contends that mandated annual audits and the submission of audited financial statements to the secretary to the treasury and the auditor general are sufficient to 
protect the public's interests. However, the reports do not require the government to provide the actual revenues and expenditures of the petroleum fund, the volumes and values of the petroleum produced, or the source of the petroleum revenue. While the audits and reports are a positive step toward transparency, a former minister of finance noted that reports and audits will not protect the public interest if the funds are poorly invested. The only direction given the Ministry of Energy and Mineral Development is that monies invested in the Petroleum Revenue Investment Reserve are to be placed in any qualifying interest account the minister prescribes, including highly speculative derivatives. Without proper leadership, these vague directives could open the system to dangerous speculation (Red Pepper, 2013).

Another potential source of public protection is the National Petroleum Authority. The Petroleum Acts intend for this agency to be politically independent in overseeing the exploration, development and production of oil and gas. Under the Acts, the Minister of Energy and Mineral Resources issues instructions to the authority regarding government policy. The authority is then expected to carry out these policies as an independent agency. The minister is also granted the power to appoint members of the board for four years, with the approval of Parliament, and can remove members for "incompetence." However, no provision is made for justifying a claim of incompetence before the Uganda Public Service Commission. The concern raised by this arrangement is whether the ministry can undermine the authority's independence because the appointees are totally dependent on the ministry for their jobs (Akello, 2014).

The National Oil Company, the second institution created under the Petroleum Acts, is charged with promoting the government's commercial oil interests. It is unclear from the legislation how the shareholders will be selected and how the interests of citizens will be represented in policy development. Should the National Oil Company evolve as a private company, it would be answerable only to the shareholders (Mawejje \& Bategeka, 2013). Another concern is the role of the Ministry of Energy and Mineral Development that has the power to issue instructions to the National Oil Company with respect to how its management tasks will be conducted and stipulating rules relating to secrecy. Consequently, opponents argue that misuse and corruption can arise given the vagueness of the law. One option to assure that state interests are being achieved is to make the National Oil Company a public company (Eller, Baler. Hartley, \& Medlock, 2011). The National Oil Company could then be privatized when accountability systems show a record of acting in the public interest is established (Magelahpeter, 2012).

\subsection{Accountability and transparity}

Accountability is particularly difficult to achieve in a country where the president and the National Resistance Movement so completely dominate the policy making process. From the ruling party's perspective, no comparable finance laws in other countries mention the parliament as often as do the laws in Uganda. The laws give extensive powers to parliament for controlling and monitoring the expenditure of public funds. For instance, the Bank of Uganda no longer has the power to guarantee any payment on behalf of the government or make any advance to the government without parliamentary approval. The difficulty with the 
government's position is that oversight requires transparency of information, but the government claims that oil companies demand confidentiality as a precondition for conducting business in Uganda. This point is reflected in the Petroleum Acts that limit the National Petroleum Authority from disclosing information about oil company operations despite the apparent conflict between this requirement and the requirements of the Access to Information Act (CSCO, 2012; Human Rights Network, 2012).

The issue of confidentiality by the oil companies may be subject to change from two quarters outside Uganda. The Dodd-Frank Wall Street Reform and Consumer Protection Act, passed by the U.S. Congress in 2010, mandates that all extractive companies traded on American stock exchanges and filing annual reports with the U.S. Securities and Exchange Commission disclose all payments made to foreign governments for the commercial development of oil. Total and CNOOC, which are highly involved in Uganda oil development, file annual reports in the U.S. and would be subject to the new disclosure rules.

The Dodd-Frank law is in part an extension of rules set by the Extractive Industries Transparency Initiative (EITI), which is an international standard for establishing transparency within the extractives sector. When governments become EITI signatories, they must agree to publish reports on the income received from extractive companies. The companies in turn publish their own record of government payments. The reports are then audited and reconciled with the results made available to the public (Ngabiirwe \& Allen, 2011). The Uganda government committed itself to joining EITI in 2008. However, no formal action has yet been taken by the government to begin the application process. Becoming a signatory to EITI would increase public information so the Uganda government can be held accountable for the fiscal management of resource revenues (Corrigan, 2014). Transparency will also serve to attract future investors in Uganda's economic development (Seyoum \& Manyak, 2009).

\subsection{Accountability and transparency}

Accountability is particularly difficult to achieve in a country where the president and the National Resistance Movement so completely dominate the policy making process. From the ruling party's perspective, no comparable finance laws in other countries mention the parliament as often as do the laws in Uganda. The laws give extensive powers to parliament for controlling and monitoring the expenditure of public funds. For instance, the Bank of Uganda no longer has the power to guarantee any payment on behalf of the government or make any advance to the government without parliamentary approval. The difficulty with the government's position is that oversight requires transparency of information, but the government claims that oil companies demand confidentiality as a precondition for conducting business in Uganda. This point is reflected in the Petroleum Acts that limit the National Petroleum Authority from disclosing information about oil company operations despite the apparent conflict between this requirement and the requirements of the Access to Information Act (CSCO, 2012; Human Rights Network, 2012).

The issue of confidentiality by the oil companies may be subject to change from two quarters outside Uganda. The Dodd-Frank Wall Street Reform and Consumer Protection Act, passed 
by the U.S. Congress in 2010, mandates that all extractive companies traded on American stock exchanges and filing annual reports with the U.S. Securities and Exchange Commission disclose all payments made to foreign governments for the commercial development of oil. Total and CNOOC, which are highly involved in Uganda oil development, file annual reports in the U.S. and would be subject to the new disclosure rules.

The Dodd-Frank law is in part an extension of rules set by the Extractive Industries Transparency Initiative (EITI), which is an international standard for establishing transparency within the extractives sector. When governments become EITI signatories, they must agree to publish reports on the income received from extractive companies. The companies in turn publish their own record of government payments. The reports are then audited and reconciled with the results made available to the public (Ngabiirwe \& Allen, 2011). The Uganda government committed itself to joining EITI in 2008. However, no formal action has yet been taken by the government to begin the application process. Becoming a signatory to EITI would increase public information so the Uganda government can be held accountable for the fiscal management of resource revenues (Corrigan, 2014). Transparency will also serve to attract future investors in Uganda's economic development (Seyoum \& Manyak, 2009).

\section{Governance and Oil Revenue Sharing}

Petroleum revenue sharing can be understood from two perspectives. The most discussed perspective is the sharing of revenues with the oil companies that provide the financial and technological investment to make production possible. Sharing takes place through production sharing agreements that are negotiated by the central government with the oil company representatives. The second perspective is sharing revenues with the local governments and citizenry that are impacted by oil production. This process is very complex in Uganda because local governments are poorly equipped to handle a large influx of money, traditional kingdoms still claim possession to vast tracts of land, and local citizens who are largely subsistence farmers often lack clear title to the land they work.

\subsection{Production Sharing Agreements}

Natural resources have little value until they are extracted and processed through heavy capital investments. Moreover, resource extraction is inherently risky as most costs are paid up-front and revenues come much later. Political and economic instability along with poor infrastructure makes extraction significantly riskier in African countries like Uganda. Consequently, governments must compete to attract exploration and development companies typically through promises of low taxes and royalties. In these volatile environments, the practice in the oil industry is for companies, called wildcatters, to obtain an exploration license from the host country. The exploration process then begins with the signing of a production sharing agreement on highly favorable terms to the wildcatter. After achieving initial success, the farming down process begins by selling the original license to a larger company with the capacity and expertise required to pull together the resources needed to extend exploration and begin actual production. The sale of the original license, which has now increased significantly in value, represents profit for the wildcatter (Anderson \& Browne, 
2011).

Farming down arose in Uganda when Heritage Oil sold its license to explore the Albertine Rife to Tullow Oil for $\$ 1.045$ billion. The Ugandan government intervened in the transaction by demanding $\$ 434$ million in capital gains tax from Heritage and suspended the exploration license until the tax was paid. The oil company objected to paying the tax because the capital gain tax was not specifically mentioned in the production sharing agreement. Moreover, the production sharing agreement was signed in 2007 while the tax code that covered oil exploration was not adopted until the following year. Heritage further claimed that Uganda had no jurisdiction because Heritage Oil was incorporated in the UK. Finally, the transaction between Heritage and Tullow took place outside Uganda (Muhame, 2013). Tullow Oil found itself in an awkward position. It could not operate under a suspended license, which in turn prohibited its attempt to farm-down by selling two-thirds of its exploration rights to Total Oil and CNOOC for $\$ 3$ billion.

Tullow broke the deadlock by agreeing to pay the Ugandan government $\$ 313$ million on behalf of Heritage Oil and then sued Heritage for this same amount. After Heritage lost a lawsuit in the Ugandan High Court, the company sought arbitration in London, as allowed under the production sharing agreement, after paying a refundable deposit of \$121 million, which equaled the tax balance due the Ugandan government. The London arbiter sided with the Ugandan government, plus Heritage Oil lost the lawsuit that had been brought by Tullow Oil. This decision brought a much needed infusion of cash into the Ugandan economy, but possibly at the cost of Uganda's ability to maintain positive relations with other oil extraction companies that might want to participate in the farming-down process (Izama \& Mulangwa, 2011).

The legal entanglement created by the initial production sharing agreement identified another complex problem. The terms of production sharing agreements are a closely guarded secret between the government and the oil companies. Lacking transparency, it is difficult for outsiders to make a reasoned judgment as to equity. Some observers speculate that oil companies' revenues are only 17\%, which is in line with the Uganda Mining Act (Kiiza et al., 2011). Other observers claim that oil companies are reaping profits that are far out of line with international standards. Moreover, the production sharing agreements bring into question the possibility of the misuse of funds resulting from signing bonuses that are not revealed to the public. It is also speculated that production sharing agreements contain a stabilization clause that protects company profits from damages caused by any future changes in the law (Lay, 2010).

\subsection{Local Revenue Sharing}

The Public Finance Management Bill calls for $7 \%$ of petroleum revenues to be allocated to the 25 local government districts that will be directly impacted by oil production. The revenues will be transferred to the districts in the form of conditional block grants that are based on the size of the local population and the amount of oil production. The law is unclear as to how royalties would be paid to traditional institutions such as kingdoms. Presumably, these payments would come from the district grants (Suruma, 2014). Another concern is that 
conditions can be placed within the block grants that are not in line with the strategic goals of the local governments. Moreover, no revenue appears to be allocated for districts affected by the oil pipeline in other parts of the country (Kashaka, 2012). A source of major opposition to the $7 \%$ allocation decision comes from the Bunyoro Kingdom, which is demanding $12.5 \%$ because it claims to serve as the trustee over much of the impacted land based on prior agreements with the British colonial government (Bunyoro, 2014).

The concern for local revenue sharing overshadows another governance issue, which is the empowerment of local citizens to participate in the decision making process. While the voices of citizens have been relatively quiet, community involvement is needed to resolve local issues before they engender open hostility. One such issue is the threat of eviction from oil production areas, interference with local industries such as fishing and agriculture, disruptions in cattle grazing due to road construction, and loss of traditional land use. These concerns will certainly increase as construction activities intensify. For instance, over 30,000 residents will be displaced with the construction of the oil refinery. While a resettlement plan is in place and oil company liaison officers have sought to engage affected communities, mistrust will continue to build without a more concerted effort to engage local citizens (Governance, 2013).

\section{Land Ownership}

Oil recovery and production is on a virtually unstoppable path in the Albertine Graben region. As development proceeds, land must be acquired and people whose lives are compromised by oil and gas development activities will need to be compensated. Present laws provide little guidance as to how land acquisition should be carried out or the legal rights of the local community (Brophy, 2014).

The question of land ownership in Uganda is incredibly complex (Ministry of Lands, Housing and Urban Development, 2009). Land ownership itself is a relatively recent concept. It was first introduced by the British to replace the established system of communal rights to agricultural land and the customary system based on the local king's domain over land. In the Albertine Graben, the British compounded the issue by taking away large tracts of land from less favored kingdoms like the Bunyoro. These lands were used to reward chiefs and notables from the rival Buganda Kingdom even though the land was already settled by farmers with customary land rights. An amendment to the Land Act passed in 2010 tried to reduce tension between owners and tenants by making it nearly impossible to evict farmers from their land for any reason other than non-payment of a nominal rental fee (Kiiza et al., 2011; Mwebaza, 2014; Rugadya, 2009; ULA, 2011). The effect has been to compromise land titles due to the fact that owners now have difficulty selling their land because they cannot evict tenants.

The land ownership problem is further complicated by the large number of ethnic groups that have migrated into the region in search of richer grazing land. The result is escalating conflicts over entitlement to agricultural lands between the Bunyoro and Bakiga groups that live in the Hoima area and more recent disputes between the Bagungu and Balaalo in the Buliisa area (Governance, 2013; Oil at the center, 2014). Both areas are in the heart of the oil production region. Another group moving into the area is land speculators who are not averse 
to fraudulent land purchases, political manipulation to gain title to customary land, and forced evictions as they position themselves for cashing in on the oil boom (Brophy, 2014; Rugadya, 2009; ULA, 2011).

Governance of ownership issues is presently through two separate legal systems that were established by the Land Act to resolve such disputes. Under this process, district land boards handle customary land disputes that do not have land titles while civil courts handle traditional ownership cases. Because of the complexities of land ownership rights, these two systems are frequently in disagreement (Mwebaza, 2014). When disagreement occurs, the Director of Land Affairs in the President's Office and local district commissioners may intervene, which often confuses the situation even more. In some instances, the oil companies reportedly circumvent the local authorities and deal directly with the inexperienced local population. The level of cooperation between the oil companies, local governments, and citizens reportedly varies considerably depending on the state of oil development in the area. Where development is more advanced, a marked improvement has been noted in infrastructure and social services (Kiiza et al., 2011). It has also increased business and social migration into these communities (ULA, 2011). Nevertheless, complaints of unfair compensation are more frequent as local citizens become aware of the increasing value of their lands (Mawejji \& Bategeka, 2013).

The government needs to develop a more effective strategy for resolving land rights issues. For instance, land titles could be awarded based on a government land survey of the affected areas (Parliamentary committee, 2012). While expensive, the government needs to take the initiative because local citizens lack the legal and financial resources to protect themselves from exploitation. Another part of the strategy would be to resolve the long-standing land dispute posed by the Bunyoro Kingdom. A possible consequence of not acting aggressively is the further dissolution of the political fabric that holds Uganda together as a nation-state.

\section{Environment}

The development of oil in the Albertine Graben, which is the most species rich eco-region for vertebrates in Africa, will have an unquestionable ecological impact. Numerous parks and wildlife-protected areas are found along Lake Albert, Lake Edward, and the Nile River. The most famous of these ecological sanctuaries are Murchison Falls and Queen Elizabeth National Parks. Thus far little comprehensive planning has gone into how oil will impact the wildlife that inhabit this pristine area as well as the expansive forest reserves (NEMA, 2009). It is also predicted that waste disposal from oil production activities could seriously contaminate underground aquifers and fishing areas (Governance, 2013). In addition, air pollution is expected as a result of smoke and toxins being released from gas flaring. One consequence is that animals, elephants in particular, will be forced to migrate out of their natural habitat and create serious crop destruction. While environmental impact assessments are required, these assessments are not readily available to the public and are much too technical for the average citizen to comprehend.

The concern for environmental protection from oil production is perhaps more of a moral than economic issue. While tourism accounts for $11.4 \%$ of Uganda's foreign exchange 
earnings, this income is dwarfed by the potential earnings from oil and gas production (Rwakakamba, Mpiira, \& Turyatemba, 2014). From a moral perspective, the public trust doctrine of the Uganda Constitution obligates the government to preserve the natural environment and ensure that present day actions do not adversely impact the biodiversity for future generations to enjoy and the livelihoods of the people who inhabit the region. This problem is particularly serious because biodiversity loss in Uganda is already estimated to be 10 to 11 percent per decade (NEMA, 2012).

One approach to protecting the fragile ecology would be to insist that production sharing agreements with the oil companies include a clause requiring "ecosystem restoration." The difficulty here is that oil companies have an advantage over the government in their understanding of the problems and costs involved in restoration while the government lacks sufficient information to verify what it is being told (Mawejji \& Bategeka, 2013). This concern is further supported by a Norwegian government study that found the biggest challenge to effective regulation of the environmental impact of oil and gas recovery is the lack of technical and financial capacity. While the Uganda government has put into place a fairly elaborate set of policies, as well as the legal and institutional mechanisms to address environmental concerns, the government largely lacks the capacity to implement these policies and laws (NEMA, 2012).

The many government agencies that are charged with managing different aspects of the environment need a significant enhancement of their human and fiscal resources to monitor and regulate oil exploration and production activity effectively. To facilitate this enhancement, an oil and gas derivation fund should be established to accumulate substantial financial assets over the life of oil production to assure sustainability and intergenerational equity (Muramira \& Manyindo, 2008). In addition, the National Resources Management Authority needs to take the lead in supervising oil waste management and disposal. Of particular concern here is the importance of emergency planning for any number of catastrophic events that might result from the rapid expansion of oil exploration and production (Parliamentary committee, 2012).

\section{Conclusion}

The excitement generated by the potential riches flowing from oil and gas production was tempered by the fall of oil prices from $\$ 120$ per barrel to less than $\$ 50$ in early 2015 along with the continuing decline in worldwide oil consumption. Investors may be much less willing to build an expensive heated pipeline to Kenya if the return on investment does not insure significant profits. When asked about the future of oil in Uganda, the Minister of Energy and Minerals Development optimistically responded that many legal structures must still be put into place to manage oil resources before going to market. The global price of oil might rebound by that time. If not, the minister claims that Uganda can still do quite well by using its domestic refining capacity to reduce dependence on expensive foreign oil and providing refined petroleum products to other East and Central African nations (Kasozi, 2014). From a governance perspective, reduced economic pressure to get Ugandan oil to the global market might give the government time to reflect on, and improve, current legislation. 


\section{Macrothink}

Journal of Public Administration and Governance ISSN 2161-7104

These laws contain serious questions with respect to governance issues. Moreover, longer-term concerns regarding land ownership and preserving the ecological environment of Uganda need to be addressed. Indeed, the present uncertainty in the global oil market may well be a blessing if it helps Uganda to avoid the natural resource curse.

\section{Acknowledgement}

The research was supported in part by the Rotary Foundation.

\section{References}

African Development Bank. (2009, March). Managing oil revenues in Uganda: A research note (Series No. 1). Proceedings of the National Seminar on Managing Oil Revenue, Kampala, 8-9 July 2008.

Akello, J. (2014, August 10). Slippery oil boards. The Independent. Retrieved December 18, 2014 from http://www.independent .co.ug

Anderson, D., \& Browne, A. (2011). The politics of oil in eastern Africa. Journal of Eastern African Studies, 5(2), 369-410.

Andrews, M., \& Bategeka, L. (2013). Overcoming the limits of institutional reform in Uganda (Paper No. 269). Cambridge, MA: Center for International Development at Harvard University.

Bainomugisha, A., Kivengyere, H., \& Tusasirwe, B. (2006). Escaping the oil curse and making poverty history: A Review of the Oil and Gas Policy and Legal Framework for Uganda (No. 20). Kampala: ACODE.

Brophy, K. (2014, 21 October). Reinforce citizens' land rights first, satisfy commercial interests after. Oil in Uganda. Retrieved from http://www.oilinuganda.org

Bunyoro. (2014, September 1). Bunyoro await oil royalties. Oil in Uganda. Retrieved from http://www.oilinuganda.org

Choudhury, C. et al. (2012). Oil: Uganda's opportunity for prosperity. New York: Columbia University, School of International and Public Affairs.

Civil Society Coalition on Oil and Gas (CSCO). (2010). Enhancing oil governance in Uganda: Critical review of the draft Petroleum (Exploration, Development, Production and Value Addition) Bill. Kampala: CSCO.

Civil Society Coalition on Oil and Gas (CSCO). (2012). Uganda: CSCO memorandum on the Public Finance Bill. The Independent. Retrieved from http://www.independent.co.ug

Collier, P. (2011). Managing Uganda's oil discovery. Oxford: Oxford University, Centre for the Study of African Economies.

Conroy-Krutz, J., \& Logan, C. (2012). Museveni and the 2011 Ugandan election: Did the money matter? Journal of Modern African Studies, 50(4), 625-655. 


\section{I Macrothink}

Journal of Public Administration and Governance ISSN 2161-7104

Cooperation. (2013, August 9). East Africa: Cooperation is strong but selective. Daily Brief Service. Oxford: Oxford Analytica.

Corrigan, C. (2014). Breaking the resource curse: Transparency in the natural resource sector and the extractive industries transparency initiative. Resources Policy, 40, 17-30. doi:10.1016/j.resourpol.2013.10.003

Deal. (2014, June). Deal signed for East African standard-gauge line. International Railway Journal, 54(6), 5.

Dorosh, P., \& Thurlow, J. (2009). Agglomeration, migration, and regional growth. A CGE analysis for Uganda (Paper 848). Washington, DC: International Food Policy Research Institute.

Eller, S., Baker, J., Hartley, P., \& Medlock III, K. (2011). Empirical evidence on the operational efficiency of national oil companies. Empirical Economics, 40(3), 623-643.

Etukuri, C. (2012, December 12). President must have control over oil-Mbabzai. In2EastAfrica. Retrieved from http://in2eastafrica.net

Gelb, A., \& Majerowicz, S. (2011, July). Oil for Uganda - or Ugandans? Can cash transfers prevent the resource curse? (No. 261). Washington, DC: Center for Global Development.

Ghazvinian, J. (2007). Untapped: The scramble for Africa's oil. Orlando, FL: Harcourt.

Hart Energy. (2013). Uganda agrees to 30,000-b/d refinery: Ends gridlock over reserves. Global Refining \& Fuels Report, 17(8), 15-56.

Henstridge, M., \& Page J. (2012). Managing a modest boom (No. 90). Washington, DC: Brookings Institution.

Human Rights Network-Uganda. (2012). Key concerns in the Petroleum (Exploration, Development and Production) Bill. Retrieved from Human Rights Network-Uganda website: http://www.hurinet.or.ug

Governance. (2013, March). Governance and livelihoods in Uganda's oil-rich Albertine Graben. International Alert. Retrieved from http://www.commercial pressuresonland.org

Izama, A., \& Mulangwa, H. (2011). Understanding the tax dispute: Heritage, Tullow, and the Government of Uganda (No. 16). Retrieved from http://www.acode-u.org

Kagai, D. (2014). Kenya, Uganda to build world's longest heated pipeline. Construction Business Review. Retrieved from http://www.constructionkenya.com

Kaija, W. (2013). MPs reject amendments in Public Finance Bill. Uganda Radio Network . Retrieved from http://ugandaradionetwork.com

Kamugisha, D., Muhereza, E., \& Elima, D. (2008). Promoting the application of access rights in Uganda's oil sub-sector (No. 4). Kampala: Africa Institute for Energy Governance.

Karugaba, M. (2013, April 10). Museveni blasts oil companies over refinery. New Vision. 
Retrieved from http://www.newvision.co.ug

Kasasira, R. (2013, June 26). Kenya, Rwanda and Uganda agree on oil pipeline. Daily Nation. Retrieved from http://www.nation.co.ke

Kashaka, U. (2012, November 21). Bank of Uganda backs new finance bill. New Vision. Retrieved from http://www.newvision.co.ug

Kashambuzi, R., \& Mugisha, F. (2003). Exploration history and petroleum potential of Uganda. Kampala: Ministry of Energy and Mineral Development.

Kasozi, A. (2014, December 25). Oil: Has Uganda lost millions by failing to catch the high price? New Vision. Retrieved from http://www.newvision.co.ug

Kiiza, J., Bategeka, L., \& Ssewanyana, S. (2011). Righting resource-curse wrongs in Uganda: The case of oil discovery and the management of popular expectations (No. 78). Kampala: Makerere University, Economic Policy Research Center.

Lay, T. (2010). Uganda's oil contracts give little cause for optimism. The Guardian. Retrieved from http://www.theguardian.com

Magelahpeter. (2012, November 5). Why a government corporation and not private company should be in charge of Uganda's interests in the petroleum sector. Legal and Policy Review Retrieved from http://lawuganda.wordpress.com

Manyak, T., \& Katono, I. (2010). Decentralization and conflict in Uganda: Governance adrift. African Studies Quarterly, 11(4), 1-24.

Manyak, T., \& Katono, I. (2011). Impact of multiparty politics on local government in Uganda. African Conflict and Peacebuilding Review, 1(1), 8-38).

Massive. (2014, January). Massive infrastructure projects. African Business. 404, 39-40.

Mawejje, J., \& Bategeka, L. (2013, September). Accelerating growth and maintaining intergenerational equity using oil resources in Uganda (No. 111). Kampala: Makerere University, Economic Policy Research Centre.

Ministry of Lands, Housing and Urban Development. (2009). National Land Policy Draft 4 of 18th September 2009. Kampala: Republic of Uganda.

Mugyenyi, O., Ustin, B., \& Twesigye, B. (2010, June 17-19). Equitable sharing of the treasures of oil and gas in a transparent and environmentally sustainable manner. A synthesis report of the Proceedings of the Parliamentary Symposium on Oil and Gas Development in Uganda. (No. 15), Entebbe, UG.

Muhame, G. (2013, December 3). Tullow Oil case: What it means for Uganda. Chimp Corporation Report. Retrieved from http://chimpreports. com

Mulondo, M. (2012). Uganda: Key reforms in public financial management. New Vision. Retrieved from http://allafrica.com. 


\section{Macrothink}

Journal of Public Administration and Governance ISSN 2161-7104

Muramira, T., \& Manyindo, J. (2008). Sharing oil and gas revenue in Uganda. Kampala: Uganda Wildlife Society.

Musisi, E. (2014, June 27). IMF calls for reforms in oil governance. Daily Monitor. Retrieved from http://www.monitor.co.ug

Musoke, R. (2014). Uganda's oil reserves now estimated at 6.5 billion barrels. The Independent. Retrieved from http://www.independent. co.ug

Mwebaza, E. (2014). A historical perspective of the land problem in Uganda. Human Rights Promotion and Awareness Forum-Uganda. Kampala: HRAPF.

National Environmental Management Authority (NEMA). (2009). Environmental sensitivity atlas for the Albertine Graben. Kampala: Republic of Uganda.

National Environmental Management Authority (NEMA). (2012). A capacity needs assessment for the environmental pillar institutions in Uganda. Kampala: Republic of Uganda.

Ngabiirwe, W., \& Allen, E. (2011). The extractive industries transparency initiative (No. 12). Retrieved from http://www.acode-u.org

Oil at the center. (2014, October 28). Oil at the center of land conflicts in the Albertine Region. Oil in Uganda. Retrieved from http://www.oilinuganda.org

Ojambo, F. (2013, June 21). Uganda awards Sinohydro contract to build Karuma hydro project. Bloomberg. Retrieved from http://www.bloomberg.com

Opinion poll. (2014, May 22). Opinion poll shows support for Yoweri Museveni. EIU Viewswire. New York: Economist Intelligence Unit.

Parliamentary committee. (2012). Report of the parliamentary committee on natural resources on the Petroleum (Refining, Gas processing and Conversion, Transportation and Storage) Bill. Kampala: Republic of Uganda.

President. (2013, April 23). Uganda: President eyes greater control over economy. Daily Brief Service. Oxford: Oxford Analytica.

Red Pepper. (2013, March 12). Suruma: Public Finance Bill weak. Red Pepper. Retrieved from http://www.redpepper.co.ug

Region. (2013, July 9). East Africa: Region begins to coordinate on oil future. Daily Brief Service. Oxford: Oxford Analytica.

Rugadya, M. (2009). Escalating land conflicts in Uganda: A review of evidence from recent studies and surveys. Washington, DC: International Republican Institute.

Rwakakamba, M., Mpiira, A., \& Turyatemba, J. (2014). Tourism in Uganda's economy: Deal or no deal! Kampala: Agency for Transformation.

Seyoum, B., \& Manyak, T. (2009). The impact of public and private transparency on foreign 
direct investment in developing countries. Critical Perspectives on International Business, 5(3), 187-206.

Suruma, E. (2014). Will parliament lose influence to the executive in the budgeting process under the new Public Finance Bill? (No.14). Kampala: Parliament Watch Uganda.

Uganda economy. (2014, January 2). Uganda economy: Preparing for an oil windfall. EIU Views Wire. New York: Economist Intelligence Unit.

Uganda Land Alliance (ULA). (2011). Land grabbing and its effects on the communities in the oil rich Albertine Region of Uganda. Kampala: ULA.

Uganda Oil \& Gas Documentation Bureau. (2014). History and development of oil \& gas in Uganda. Kampala: ACODE.

Van Alstine, J., Manyindo, J. Smith, L., Dixon, J., \& AmanigaRuhanga, I. (2014). Resource governance dynamics: The challenge of 'new oil' in Uganda. Resources Policy, 40, 48-58. doi:10.1016/j.resourpol.2014.01.002

Walubiri, M., \& Mulondo, M. (2014, July 17). NRM, opposition spar over Public Finance Bill. New Vision. Retrieved from http://www.newvision.co.ug

Wiebelt, M., Pauw, K., Matovu, J., Twimukye, E., \& Benson, T. (2011). Managing future oil revenue in Uganda for agricultural development and poverty reduction (No. 01122). Washington, DC: International Food Policy Research Institute.

Wiebelt, M., Schweickert, R., Breisinger, C., \& Böhme, M. (2011). Oil revenues for public investment in Africa: Targeting urban or rural areas? Review of World Economics, 147(4), 745-770. doi: 10.1007/s10290-011-0101-2

\section{Copyright Disclaimer}

Copyright reserved by the author(s).

This article is an open-access article distributed under the terms and conditions of the Creative Commons Attribution license (http://creativecommons.org/licenses/by/3.0/). 